\title{
REUNIÃO DOS EDITORES
}

No final do mês de maio, a Editoria de Química Nova e seus Editores Associados se reuniram para discutir os rumos da revista e traçar novas estratégias para os próximos anos. Neste editorial gostaríamos de trazer ao conhecimento dos membros da SBQ algumas destas reflexões e preocupações e, também, sugestões aos nossos leitores e colaboradores.

Vamos terminar o ano de $2010 \mathrm{com}$ aproximadamente o mesmo número de publicações de 2009, considerando o que já existe de artigos aceitos e em processo de revisão. Serão aproximadamente 900 artigos submetidos no total em toda Química e áreas afins. O tempo entre submissão e aceite tem diminuído, mas não tanto como gostaríamos. O aceite dos assessores ad hoc deveria ser mais rápido e aqueles que não aceitarem dar parecer, por alguma razão, poderiam gentilmente indicar para QN um pesquisador que pudesse emitir parecer para o trabalho. Aceitar dar parecer e deixar de responder depois é muito ruim para a revista, pois é um dos motivos de atraso no tempo de avaliação dos manuscritos. Neste sentido, a expectativa dos editores é que os pesquisadores seniores deveriam contribuir mais efetivamente nos pareceres. Sabemos o quanto somos todos ocupados, mas as nossas revistas representam o brasão da SBQ, sendo vistas por setores da política de fomento à ciência como nosso cartão de visita. Indiretamente, recursos conquistados pela área de Química para projetos de pesquisa e bolsas de estudo estão relacionados ao sucesso das revistas da SBQ.

Devido ao sucesso de QN, traduzido num índice de impacto realístico para uma revista que publica artigos em geral de química em diversos idiomas, constatamos que está havendo um crescimento muito elevado de publicações nas áreas afins, como as de alimentos, validação de produtos farmacêuticos, monitoramentos, qualidade de águas, atmosfera e solos, dentre muitas outras. Estes artigos aumentam consideravelmente o tempo de tramitação e publicação, pois os assessores ad hoc não são da área. Química Nova não pretende ser uma revista hermética só na área de química, até porque é nas interfaces que estão os trabalhos mais importantes e relevantes para a ciência. Porém, algumas das submissões são recusadas por estarem totalmente fora do escopo da revista e outras apenas utilizam técnicas adequadas, mas não contêm ineditismo e novidade. Deste modo, continuaremos com a política de aceitar artigos originais e revisões que apresentem resultados inéditos, relevantes e que contenham contribuições para a Química.

Continuamos a incentivar a publicação de revisões, porém entendemos que não se trata de uma introdução de tese de mestrado ou doutorado. Os pesquisadores que desejam colaborar com revisões devem encaminhar documento com 3-4 páginas mostrando sua experiência na área, a pertinência do tema e referenciar as revisões mais recentes publicadas na literatura. Desejamos que os artigos de revisão reflitam temas atuais na fronteira do conhecimento e com análise crítica da área em que está inserida a revisão. Uma compilação de dados da literatura sem organização histórica, didática e da trajetória futura para o tema, mesmo que realizada por pesquisadores que contribuam ativamente para a área, pode ser adequada para uma introdução de tese, mas não como uma revisão para QN. As nossas revisões são tão boas, ou melhores, do que muitas outras publicadas em diversos periódicos.

Finalmente, é sempre bom lembrar dois aspectos importantes que temos escrito em nossos editoriais: as correspondências dos autores devem ser sempre via plataforma e não para os endereços eletrônicos dos editores e que não nos esqueçamos de citar os trabalhos publicados em Química Nova e JBCS.

A Editoria de Química Nova e seus Editores Associados têm a consciência dos novos desafios que têm pela frente como o de ampliar (ou manter) seu índice de impacto mesmo aumentando o número de artigos por fascículo, aumentar a periodicidade para um fascículo por mês, diminuir o tempo de tramitação e aceite dos trabalhos, ampliar a capacidade de gerenciamento em face ao elevado número de artigos submetidos e mais, diminuir os custos da revista que é financiada em grande parte com recursos da própria SBQ.

Acreditamos que este é o rumo correto e a nossa preocupação permanente é como manter uma revista científica confiável e com alto padrão científico.

Susana I. Córdoba de Torresi Vera L. Pardini Vitor F. Ferreira Editores de QN

Aldo J. G. Zarbin Débora de A. Azevedo Jorge M. David Marco T. Grassi Rochel M. Lago Editores Associados 